\title{
Impact of Corona Virus on Criminal Action and Prevention Measures in Indonesia
}

\author{
I Ketut Seregig ${ }^{1 *}$, Bambang Hartono ${ }^{2}$ and Budi Waskito ${ }^{3}$ \\ 1,2 Lecturer of Faculty of Law, Universitas Bandar Lampung, Indonesia \\ ${ }^{3}$ Lecturer of Faculty of Social and Political Science, Universitas Bandar Lampung, Indonesia \\ *ketut1183@gmail.com and bambang.hartono@ubl.ac.id
}

Published: $15 / 08 / 2020$

How to cite: Seregig, I. K., Hartono, B., \& Waskito, B. (2020). Impact of Corona Virus on Criminal Action and Prevention Measures in Indonesia. Sociological Jurisprudence Journal. 3(2). 117-125. https://doi.org/10.22225/scj.3.2.1823.117-125

\begin{abstract}
This article is data obtained from interviews with traders in traditional and modern markets about the impact of criminal acts due to the corona virus outbreak in Indonesia. The data is supported by secondary data collected from official sources, among others published by the ministry of trade and other social media. The purpose of writing this article is to provide input on a corona virus epidemic prevention plan and mitigate the impact of criminal acts due to hoax news related to corona virus outbreaks. The impact of the corona virus outbreak in the community is the accumulation of protective masks that cause the price of masks to rise in the market, the spread of hoaxes by people who are not responsible, among others; hoax news with the contents "corona virus cannot stand the heat", and "red ginger, kaempferiagalanga, curcuma, pepper are considered as drugs that can fight the corona virus" which results in an increase in the price of rhizomes and spices and is becoming rare in the traditional market. The stakeholders under the coordination of the Coordinating Ministers undertook strategic actions including the National Police and the Ministry of Health and the Regional Head who carried out market operations for the distribution of masks, ginger and spices distribution in traditional markets. As a result, the team formed by the National Police, assisted by the Ministry of Health, succeeded in capturing mask hoarders in the Jakarta area. The hoarders are prosecuted by carrying out law enforcement and bringing the perpetrators to justice.
\end{abstract}

Keywords: Corona Virus Outbreak, Criminal Impact, Countermeasures

\section{INTRODUCTION}

Corona virus disease (hereinafter referred to as Covid-19) is a virus that has symptoms of fever, coughing and shortness of breath for sufferers. The emergence of this virus first attacked one of the Yunan residents in the State of China, then spread very quickly to other areas in China. The spread is through mucus that comes out of a person who is infected with Covid-19 whose symptoms are coughing or sneezing and shortness of breath. If this direct relationship occurs with someone who does not know that the patient has contracted Covid-19, then someone who has that relationship is most likely to be infected by this virus. Therefore Covid-19 is not only endemic in mainland China.

The spread of Covid-19 is pandemic and can develop at various temperatures. This has been proven in just three (3) months, the spread of this virus has spread to more than one hundred (100) countries in the world that have different natural conditions, namely; cold, hot, and cool air. The development of Covid-19 is not in the air temperature, but through direct contact and mucus released by the patient due to coughing into people who have close contact with the patient. Therefore, in taking precautions, the handling of every person suspected of contracting the virus based on United Nations guidelines is to carry out isolation (quarantine) during the Covid-19 incubation period, which is for fourteen (14) days. At that time, a person suspected of contracting the virus was carried out a series of tests and laboratory tests in order to detect Covid-19. If within fourteen (14) days, a person suspected of being infected with Covid-19 has been carried out a series of tests and laboratory tests, it turns out that the virus itself is not suspected and three (3) general physical symptoms do not occur as mentioned above, it can be ascertained the quarantined person can be concluded Negative Covid-19. 
The spread of Covid-19 until now there is no drug that is definitely able as an antidote or healer for people infected with this virus. The efforts made by doctors to date have been to take hygienic steps and increase the patient's immune system by giving antibodies or antivirals that are generally possible for antiviral SARS or even bird flu (H5N1). Due to this situation and condition, the Minister of Health stated that the virus is not dangerous or the level of Covid-19 danger for infection is very small. This statement finally led to diverse interpretations in the community. Some responded that the corona virus could not stand the heat so humans had to consume food and drinks that had quality intake as body warmers such as ginger, kaempferiagalanga, curcuma, and spices.

Due to the different interpretations that are viral in the community through social media, the community members are competing to buy up ginger, kaempferiagalanga, curcuma, and spices on the market. This has caused the price of raw materials to surge in the market. There are more citizens who are paranoid due to statements from stakeholders who say that until now the Covid-19 antivirus has not been found. The impact is that people are competing to buy up food to be stocked at home with the intention to reduce traveling outside the house so that they do not meet other people. The impact that occurred was as a result of public panic towards the Covid-19 outbreak.

Of course, a momentum of events that occur will impact on various lines in the community. So through this research, several things that would be relevant to be discussed will be examined, including: 1. What is the effect of co-19 on economic conditions in traditional markets? 2. How does co-19 affect the quantity of crime that occurs? 3. What steps can be taken as an effort to deal with the criminal impacts that occur due to covid-19?

\section{METHOD}

This research uses the methodology of empirical legal research, so through a research sample in Bandar Lampung, the author draws a general conclusion to describe the conditions in Indonesia. in this context, of course the influence of the co-19 issue on the Indonesian economy and the level of crime related to co-19.

\section{RESULTS AND DISCUSSION}

Quoting the results of research from Harvard T.H. Chan School of Public Health in the United States which doubts that in Indonesia as of 11/2/2020 there has not been a single positive report on corona viruses in Indonesia and published data on deaths from new types of corona viruses (novel coronavirus) reached 1,018 people with a total of 43,103 cases (data Tuesday, 11/2/2020). The results of the published research have not been tested but only limited to predictions so they cannot be used as valid data.

Responding to the results of research from the Harvard T.H.Chan School of Public Health research team of the United States who doubted Indonesia's ability to handle the corona virus, dr. Siswanto as Head of Research and Development of the Ministry of Health of the Republic of Indonesia clarified that Indonesia has the ability to identify corona virus through the National Research and Development Laboratory of the Indonesian Ministry of Health. This laboratory has experience in handling cases of SARS, Avian Influenza and MERS which basically uses the same method and approach, namely the biomolecular approach - genomic approach, so that the examination uses the Polymerase Chain Reaction (PCR) method, meaning by multiplying DNA or RNA. The community does not need to respond because the data is only a prediction from the research team (accessed 10/03/2020, from 'kumparanSAINS' 12/02/2020)).

To provide understanding to the public, the statement of the Head of Laboratory of Research and Development Agency of the Republik of Indonesian Ministry of Health, dr. Siswanto gave a statement regarding the handling of AI, MERS and SARS cases in Indonesia as follows:

\section{Handling of Avian Influenza Cases}

The first case of a human being infected with Avian Influenza in Indonesia was in 2005. The scientific journal 'Nature' states that at that time Indonesia was the fourth country in Southeast Asia to report positive citizens contracting the $\mathrm{H} 5 \mathrm{~N} 1$ virus. Meanwhile in Vietnam, Cambodia and Thailand, in the same year the death toll from bird flu reached 54 people. The first case of bird flu in Indonesia 
happened to a man who worked on a farm. The identification results revealed a virus infected victim from sick farm chickens. At that time, a total of 81 people were suspected of being exposed to the virus from the same location, but after all blood samples were tested in a laboratory in Hong Kong, only 1 person tested positive for bird flu.

Since August 2006 examinations to confirm avian influenza cases have been carried out in Indonesia in collaboration with the Health Research and Development Agency, the Eijkman Institute, Jakarta and the Navy's Second Medical Research Unit (NAMRU-2). Then, in December 2006 the Biomedical and Pharmaceutical (BMF) Research and Development Center Laboratory, the Indonesian Ministry of Health, was established as the national reference laboratory for the diagnosis of avian influenza in Indonesia. Guidelines for the collection, handling and delivery of specimens from patients suspected of being infected with bird flu have been established by BMF Research and Development Center. In this examination BMF conducts RT-PCR or Reverse Transcriptuse Polymeruse Chuin Reaction laboratory tests, both gel-based and real-time, to detect influenza A (H5N1) virus RNA and perform serological tests to detect the presence of H5N1 virus antibodies. Since it first appeared in Indonesia in 2005 to October 2017, WHO noted that H5N1 has infected 200 people with 168 deaths. This disease has symptoms including vomiting, diarrhea, bleeding gums, pain in the chest, nosebleeds, to lung infections and multi-organ failure.

\section{Handling of MERS Virus}

The case of MERS, which is still a family with SARS and a coronavirus novel, has not been found to be positive in Indonesia. This disease had more attacks the population in the Middle East since September 2012. But the threat of MERS-CoV needs to be watched out. As a preparedness effort, Indonesia has compiled laboratory examination guidelines for the MERS-CoV virus. Guidelines for collecting specimens and laboratory examinations issued by the Indonesian Ministry of Health states that the type of specimens that must be examined are the sputum of the patient, a combination of nasal and throat swabs, nasopharyngeal swabs and serum for serology or virus detection.

\section{Handling of SARS Virus}

The situation in Indonesia at the time of the SARS outbreak was not much different from bird flu and MERS. Based on a report published on the official website of the Ministry of Health of Indonesia up to May 8, 2003, five (5) suspect cases and two (2) probable SARS cases in Indonesia were found, and all of these patients had recovered and were discharged from the hospital. As an anticipatory measure against the SARS virus, the government appointed thirty-four (34) referral hospitals in the response to SARS. All of these hospitals have been trained, ranging from how to collect samples to delivery by experts from Emory University, Atlanta and NAMRU. Each hospital has also been equipped with tools for laboratory tests (Kumparan.com, 2020). To illustrate the comparisons of the corona virus / COVID19 virus levels, we will describe the data reported by WHO, CDC, Washington Post and Coils with the following comparisons:

Table 1

Comparison of Covid 19 data

\begin{tabular}{ccccc}
\hline COMPARISON OF COVID-19 CASE & POSITIVE CASE & DEATH & DEATH RATE & $\begin{array}{c}\text { STATE } \\
\text { contagion }\end{array}$ \\
\hline Corona Virus/COVID-19 (2019- & 95.333 & 3.282 & $3,44 \%$ & 80 \\
2020) & & & & \\
SARS (TH 2003) & 8.098 & 774 & $9,56 \%$ & 26 \\
MERS (TH 2012-2019) & 2.499 & 861 & $34,45 \%$ & 26 \\
EBOLA (TH 2014-2016) & 28.616 & 11.310 & $39,52 \%$ & 11 \\
CAMPAK (2018) & 9.760 .400 & 142.300 & $1,46 \%$ & 182 \\
\hline
\end{tabular}

Source: WHO, CDC, CNA, Washington Post andKumparan Data: 5 March 2020.

Based on the data table above, the risk of death due to corona virus is $3.44 \%$ compared to SARS virus $9.54 \%$ and MERS $34.45 \%$. Likewise, the number of affected countries is 80 (possibly increasing) compared to the much lower spread of SARS and MERS. With the analysis of these facts, there is no reason for people to fret and worry about the corona virus outbreak. However, it is necessary to be 
vigilant and avoid direct contact with people suspected of being exposed to the corona virus. In communicating, we must keep our distance from the speaker so that we are not too close.

Based on the latest development of the corona virus pandemic in Indonesia derived from data published by Spokesperson of the Corona Indonesia Virus Management Agency, AchmadYurianto stated that the number of Indonesians infected with the corona virus as of March 12, 2019 totaled 34 people.

\section{Impact of Corona Virus Outbreak on the Economy}

The chronology of the emergence of the Covid-19 outbreak began on December 31, 2019. The Wuhan China Public Health Commission reported an outbreak of pneumonia-like illness that spread with 27 cases confirmed positive. Furthermore, the Chinese government revealed the initial symptoms of this virus had appeared since early December 2019, especially around the Food Market, in the Wuhan Huanan Sea of China. Then on January 9, 2020, Chinese scientists identified the outbreak as being caused by a new type of corona virus. Transmission of this new virus resembles the SARS outbreak that spread from China in 2002 ago. This corona virus can infect animals and humans. However, this new type of corona virus has not yet been identified in its transmission, whether through air or humans.

Then on the third day of the outbreak, which was on January 12, 2020, the Chinese government announced that there had been a death of a 61-year-old man from Wuhan who was caused by the outbreak of the new corona virus. This is evidenced by the fact that three days before the victim contracted the new corona virus. Transmission of the corona virus is very high. Transmission of the corona virus out of China for the first time occurred on January 13, 2020, namely in Thailand and then followed on January 16, 2020 similar cases occurred in Japan, the first in the country. And, on January 20, 2020, this corona virus spread and after checking two more patients proved positive outside of China, namely South Korea and Taiwan.

A week after the World Health Organization (WHO) warned that transmission of the corona virus outbreak was most likely to occur between humans. This is confirmed by Chinese health experts that the spread of the new corona virus is from human to human. Then on January 21, 2020 the United States announced the first case in Washington against a man in his 30s where he had just returned from Wuhan China. On January 22, 2020, China said the new virus was able to adapt and mutate and said the second foreigner infected in China was Thai. Then on January 23, 2020 China announced that three cities in China were quarantined and around 20 million residents were barred from leaving.

On January 25, 2020, China's Global Television Network in its news broadcast stated that dr. Liang Wudong (age 62) who served in the Wuhan Hubei Xinhua Hospital was declared dead due to the corona virus. Then Malaysia announced that four of its citizens were confirmed to be infected with the corona virus. Furthermore, on January 26, 2020, the Chinese government stated that 56 people died in China due to the corona virus and more than 2000 people were infected with the corona virus. On January 27 , 2020 , the number of dead people had increased to 80 (Wijaya, 2020).

The results of data collection from 'nasional.kompas.com' until March 7, 2020, Covid-19 transmission has spread to 73 countries, with 48,002 treatments recovered, 3,117 died. Consecutively the 73rd in various parts of the world that were positively affected by Covid-19 are as follows:

China (origin of the plague), South Korea, Italy, Iran, Japan, France, Germany, Spain, Singapore, United States, Kuwait, Bahrain, Thailand, Taiwan, United Kingdom, Australia, Malaysia, Canada, Switzerland, Iraq, United Arab Emirates, Norway, the Netherlands, Vietnam, Sweden, Austria, Israel, Lebanon, Belgium, Croatia, Greece, Ecuador, Finland, India, Oman, Russia, Algeria, Mexico, Denmark, Pakistan, Philippines, Azerbaijan, Czech Republic, Georgia, Iceland, Qatar, Romania, Belarus, Brazil, Egypt, Indonesia, Portugal, Afghanistan, Andorra, Armenia, Cambodia, Dominican Republic, Estonia, Ireland, Jordan, Lithuania, Luxembourg, Monaco, Morocco, Nepal, New Zealand, Nigeria, Northern

Macedonia, San Marino, Saudi Arabia, Senegal, Sri Lanka and Tunisia (Bramasta, 2020).

Specifically in Indonesia the number of people infected with Covid-19 transmission is very fast, namely; 96 positive people, recovered 8 people and died 5(Pratiwi, 2020). To avoid the transmission of the corona virus, the Jakarta Special Capital City government has closed all schools and sought to learn using the video conferencing method. The Minister of Education and Culture, Nadiem Makariem, 
instructed to postpone all school and campus activities that invite people to avoid and cut off the transmission of the corona virus.

Since President Joko Widodo stated that two (2) residents were infected with the corona virus outbreak, to date 96 people have been positive of the corona virus, as reported by a spokesman for the Corona Virus Prevention Agency, (Pratiwi, 2020). Quantitatively, the impact on the economy, especially foreign trade, has not been so great, but the quality of the Indonesian economy continues to decline. The Ministry of Trade of the Republic of Indonesia based on foreign trade statistics in general launch the following data:

Table 2

The Ministry of Trade of the Republic of Indonesia based on foreign trade statistics

\begin{tabular}{|c|c|c|c|c|c|c|c|}
\hline \multirow{2}{*}{ DESCRIPTION } & \multirow{2}{*}{2018} & \multirow{2}{*}{2019} & \multirow{2}{*}{ Trend $(\%)$} & \multicolumn{2}{|c|}{ JANUARY } & \multirow{2}{*}{\multicolumn{2}{|c|}{ Change (\%) }} \\
\hline & & & & 2019 & 2020 & & \\
\hline TRADETOTAL & $368,724.0$ & $338,224.4$ & 5.75 & $28,919.3$ & $27,900.8$ & \multicolumn{2}{|c|}{ average: $-\mathbf{- 3 . 2 7}$} \\
\hline OIL AND GAS & $47,040.1$ & $34,389.2$ & -0.65 & $2,891.3$ & $2,803.3$ & \multicolumn{2}{|c|}{-3.04} \\
\hline NON-OIL AND GAS & $321,683.9$ & $303,835.2$ & 6.69 & $26,028.0$ & $25,097.5$ & \multicolumn{2}{|c|}{-3.50} \\
\hline EXPORTTOTAL & $180,012.7$ & $167,497.0$ & 4.40 & $13,927.9$ & $13,632.0$ & average: & -1.47 \\
\hline OIL AND GAS & $17,171.7$ & $12,504.7$ & -5.08 & $1,234.7$ & 816.2 & \multicolumn{2}{|c|}{-3.90} \\
\hline NON-OIL AND GAS & $162,840.9$ & $154,992.2$ & 5.48 & $12,693.2$ & $12,815.9$ & \multicolumn{2}{|c|}{0.97} \\
\hline IMPORTTOTAL & $188,711.4$ & $170,727.4$ & 7.13 & $14,991.4$ & $14,268.7$ & average: & 6.03 \\
\hline OIL AND GAS & $29,868.4$ & $21,884.4$ & 2.34 & $1,656.6$ & $1,987.1$ & \multicolumn{2}{|c|}{19.95} \\
\hline NON-OIL AND GAS & $158,842.9$ & $148,843.0$ & 8.00 & $13,334.8$ & $12,281.6$ & \multicolumn{2}{|c|}{-7.90} \\
\hline $\begin{array}{c}\text { TRADING } \\
\text { BALANCETOTAL }\end{array}$ & $-8,698.7$ & $-3,230.4$ & 0.00 & $-1,063.5$ & -636.7 & average: & 2,85 \\
\hline OIL AND GAS & $-12,696.7$ & $-9,379.7$ & -18.45 & -421.9 & $-1,170.9$ & \multicolumn{2}{|c|}{-177.57} \\
\hline NON-OIL AND GAS & $3,998.0$ & $6,149.3$ & -25.45 & -641.7 & 534.3 & \multicolumn{2}{|c|}{183.26} \\
\hline
\end{tabular}

Source: BPS (Statistics Indonesia), processed by the Center for Data and Information Systems, Ministry of Trade of the Republic of Indonesia, accessed on March 8, 2020.

Based on the statistical data above, it can be analyzed that there was a change in the total value of foreign trade in January 2019 USD 28,919.3 and January 2020 USD 27,900.8 with a change in decline of $3.27 \%$. In general, the impact of a decline in foreign trade (export-import) was $3.57 \%$, which consisted of oil and gas trade, down 3.04\% and non-oil and gas down 3.50\%. In general, exports declined by $1.47 \%$, which consisted of oil and gas exports down $3.90 \%$ and non-oil and gas products falling $0.97 \%$. Imports on average generally rose by only $6.09 \%$ consisting of oil and gas up $19.95 \%$ and non-oil and gas down $7.90 \%$. Analysis of this data shows that within 1 month the decline in foreign trade was still not felt (Indonesian Ministry of Trade's Foreign Trade Statistics Portal, (http:// statistik.kemendag.go.id/infographic/perkembangan-perdagangan-luar-negeri).

Press Release Public relations bureau of the Ministry of Trade of the Republic of Indonesia from Building I Floor 2, M.I. Ridwan Rais St. No. 5, Jakarta 10110 Tel: 021-3860371/Fax: 021-3508711 www.kemendag.go.id stated:

In anticipating the impact of the corona virus in the Indonesian economic sector, Minister of Trade AgusSuparmanto made efforts to improve coordination between the Ministry of Trade and the Indonesian Embassy in Beijing to overcome the impact of the corona virus on the economy, especially Indonesian trade. With this synergy and coordination, the Indonesian government will be able to obtain early information on the condition of China to determine the strategic steps that need to be taken in relation to increasing exports and imports for export and industry orientation including domestic trade.

This policy was conveyed by the Indonesian Minister of Trade on Wednesday, March 4, 2020 through a video conference with the Indonesian Ambassador in China. The video conference was held at the 2020 Ministry of Trade Work Meeting held on March 4-5, 2020 in Jakarta related to the Covid-19 outbreak in China. It is hoped that business people in Indonesia can more quickly get the latest developments regarding the economy in China. Regarding the corona virus outbreak, Indonesia did not close imported products, especially capital goods. The Ministry of Trade only applies a temporary halt to 
imports from China, especially for live animals.

The Indonesian ambassador in China, Djauhari, conveyed the current condition of the Chinese economy after the outbreak of the corona virus. This happened after the China-United States trade war which resulted in slowing the performance of Chinese exports. China is the second economic power now after the US. This condition is very influential on Indonesia's economic conditions, especially national industries that require raw materials from China. According to WHO the corona virus outbreak has now passed its peak condition and is experiencing a downward trend. At the end of February 2020, the President of China had instructed his industry to be fully operational again (Jakarta, March 5, 2020).

With this information, Indonesia is expected to be ready to take the opportunity to pursue the 2020 export target. For example, by immediately resolving trade barriers, such as the export of fruits, swallow nests, and SME products(Andrianita, 2020).

To find out the impact of the corona virus outbreak on the market economy, we conducted random interviews with economic actors in the field which were used as samples to represent the actors of the modern market economy and traditional markets. Chandra Supermarket Manager, Jimmi, (representing modern market participants; Interview, 08/03/2020) stated that retail goods are relatively stable, but the decrease in sales turnover occurs in ready-to-eat foods by around 10\%; Safari Gold Shop, Rani, (representing gold traders; Interview, 08/03/2020) stated that its sales turnover decreased by 10-20\%, the market was relatively quiet, most consumers sold jewelry rather than buying; "Darlene Steaks" Restaurant Manager, Lenny, (representing Restaurant owner; Interview, 08/03/2020) stated that sales turnover in February 2020 decreased by $10 \%$ and did not know whether it was caused by the corona virus outbreak issue or not, but it was clear turnover decreased; Chicken meat sellers at the Lampung Lukung Bay Lampung Warehouse Market, Lela, (representing traditional market players; Interview, 08/03/2020) stated that since the corona virus outbreak, sales have become quiet and turnover has decreased to $25 \%$, chicken stock has always remained.

Information from market participants in the field can be analyzed, that since the outbreak of the corona virus, the market economy has tended to decline, although the decline was not significant. This is in line with foreign trade balance analysis data reported by the Ministry of Trade of the Republic of Indonesia dated March 4, 2020 which states that the issue of the Covid-19 outbreak has corrected the total value of Indonesia's foreign trade, oil and gas and non-oil and gas by $3.27 \%$.

\section{Impact of Corona Virus Outbreak on Criminal Acts}

As a result of the outbreak of the Covid-19 outbreaks, it has had a criminal impact on society, particularly criminal offenses in the economic field and cybercrime. As an illustration, this will be described as follows:

\section{Impact on Economic Crimes}

The impact of the Covid-19 outbreak on economic crimes included the crime of hoarding masks needed by the community as a respiratory protector. The steps taken by the National Police as Law Enforcement officers continue to conduct investigative efforts to find the perpetrators of stockpiling of masks, which causes traders' stock masks to become scarce and the prices of masks to continue to rise in the market. Investigation efforts carried out by the National Police succeeded in arresting the perpetrators of hoarding masks and hoaxes related to the corona virus outbreak. Below will be displayed a visualization of capturing the mask hoarding as follows:

The Head of the Indonesian Police Criminal Investigation Agency, Commissioner General ListyoSigit, in the operation of mask hoarders in all regions of Indonesia, stated that for the first time in history the police cracked down on mask hoarders as many as twenty-five (25) people. This result is the largest number in the history of the capture of commodity stockpiling. The National Police is currently investigating thirty (30) perpetrators intensively in the Criminal Investigation Police Unit (press release, 5/3/2020). Head of the Public Relations Division of the Police Public Relations Division, Chief Commissioner Asep Adi Saputra, said that twenty-five (25) perpetrators arrested consisted of seventeen (17) cases that occurred in Jakarta, West Java, East Java, Central Java, Banten, Riau Islands, South Sulawesi, West Kalimantan and East Kalimantan. Of the seventeen (17) cases we divided into two, twelve (12) were hoarding masks and hand sanitizers and five (5) cases were spreading false news 
(https://haluanlampung.com/2020/03/06/ history-new-action-25-hoarder-mask-secured /).

\section{Impact on Cyber Crimes}

The impact of the Covid-19 outbreak on cybercrime included the large amount of hoax news through social media. This impact occurred after the President of Indonesia, Joko Widodo, first announced that two (2) positive Indonesians were infected with Covid-19 and until now the transmission continues and is very fast, so that in Indonesia the number of infected with Covid-19 has reached 96 people positive (data: 3/14/2020). The Ministry of Communication and Information Technology (Kominfo) also announced that it has found a lot of hoax information related to Covid-19. As of Tuesday (2/3/2020), the Ministry of Communication and Information has found 147 news of hoaxes related to the Covid-19 outbreak.

The results of a summary of the report submitted by FerdinandusSetu as the Head of the Republic of Indonesia Ministry of Communication and Information Bureau stated that the corona virus had entered Palu; Vitamin D is effective in preventing corona virus infection; Information from the Ministry of Health Regarding 6 Yellow Zone Cities; corona virus in Indonesia has entered Indonesia, 136 corona patients are under surveillance; Mohammad Hoesin Hospital Palembang treated one patient suspect corona virus. While the National Police in its law enforcement activities have succeeded in arresting 5 perpetrators involved in the case of spreading hoax or news related to the Covid-19 outbreak. The five people are currently still in the process of investigating the Director of Cybercrime Criminal Investigation Police (https: //haluanlampung.com / 2020 / 03 / 06 /sejarah-baru-penindakan-25penimbun-masker-diamankan/).

In the community there are also rumors that to ward off the corona virus, we have to drink warm ginger water, drink curcuma or kaempferiagalanga herbs so that the body gets warm because the corona virus cannot stand the heat. So, if the body is given an intake that warms the body, those who drink herbal medicine will not be exposed to the corona virus. This hoax news has led to speculation of vegetable and spice traders in traditional markets. The price of Ginger/Red Ginger rises from Rp.25,000 per $\mathrm{kg}$ to Rp.40,000 per $\mathrm{kg}$, kaempferiagalanga rises from Rp.40,000 per $\mathrm{kg}$ to $\mathrm{Rp} .65,000 \mathrm{per} \mathrm{kg}$, curcuma rises from Rp.5,000 per $\mathrm{kg}$ to $\mathrm{Rp} .15,000$ per $\mathrm{kg}$. These facts were obtained based on information from Ms. Gino (representing traditional traders; interview, 03/09/2020) at the Pasir Gintung traditional market, Tanjungkarang, Bandar Lampung.

Based on the facts above can be analyzed, news hoaxes have damaged the price stability of ginger, kaempferiagalanga, curcuma in traditional markets. This also affects the prices of other seasonings. The facts mentioned above can be taken into consideration for law enforcement officials in carrying out market operation steps and disseminating information on the corona virus outbreak issue correctly and in stages to the public. In doing so they must coordinate with local offices and agencies so that they do not overlap.

\section{Efforts to tackle the impact of the Corona Virus Plague}

The strategic effort undertaken by the government in tackling criminal offenses related to the Covid19 outbreak is to prioritize police officers to carry out pre-emptive, preventive and repressive actions in an integrated manner between the police at the central and regional levels with the following activities:

\section{Pre-emtif Activity}

This activity is an education (counseling) with appeals through print media and electronic media, leaflets, pamphlets posted on the streets which essentially tells the public not to spread hoaxes and do not hoard the basic needs of the community. This is the time for the Indonesian people to show the world about mutual cooperation, unity in dealing with the corona virus. Do not take advantage of the hardships we face to find personal gain.

\section{Preventive Activity}

Prevention efforts carried out by Bhayangkara Trustees of Security and Public Order by patrolling, attaching leaflets and appeals in strategic places such as neighborhoods RT, RW whose contents include, among others:

a. Time to be together to face corona 
b. Show to the world, we are the nation of discipline in facing corona

c. Do not travel if it is not important

d. Face corona with technology: // work, pray \& other activities from home

e. Don't become a criminal, at a time to war against corona

f. Corona stunning; don't shake hands, set the distance when speaking - only one meter.

3. Repressive Activity

This activity is carried out by the Republic of Indonesia Police Criminal Board which in its implementation involves PPNS (Civil Servant Investigators) in accordance with their fields and is carried out from the central to the regional level. Specifically, for the National Police, they carry out special cyber police operations targeting Hoaxes and special police operations targeting "basic needs". This activity will be able to give a deterrent effect to the perpetrators who commit violations by utilizing the corona virus outbreak situation. For example, actors who hoard masks with a view to raising the price of goods or hoarding and raising the price of groceries as a result of the temporary stoppage of basic food imports by the Ministry of Trade. Likewise, the perpetrators who spread hoaxes caused anxiety in the community.

\section{CONCLUSIONS}

The criminal impact arising as a result of the Covid-19 outbreak in Indonesia can be summarized as follows: The impact of the Corona Virus outbreak had a major impact on the condition of the Indonesian economy. Based on the facts studied, commodity prices in traditional markets in Bandar Lampung rose by an average of $15 \%-35 \%$ (prices of Ginger, kaempferiagalanga and curcuma) while the sales turnover of food traders in modern markets and restaurants decreased by an average of $10 \%-20 \%$ (research sample in Bandar Lampung). The impact of the Corona Virus outbreak on criminal offenses is quite large. Based on data from the actions taken by the Criminal Investigation Police Unit, there were 25 perpetrators who hoarded masks and 5 perpetrators of hoaxes. The perpetrators have now been investigated by the Police Criminal Investigation.

Efforts that must be made in pre-emptive activities are educational activities (counseling) by way of appeals through print and electronic media, leaflets, pamphlets, which are posted on the streets. The point is to tell the public not to spread hoaxes and not to stock up on the staples needed by the community. Prevention efforts are carried out by attaching pamphlets and leaflets containing appeals in strategic places, within the Community Association. The contents include: It's time we worked together to face Corona; Show the World, We Are Disciplined Nation Facing Corona; Don't Travel When It's Not Important; Face Corona With Technology://Work, Pray \& Other Activities, All From Home; Don't Be a Criminal, While the Nation Is Fighting Against Corona Virus; Corona Stalking; Don't Shake My Hand, Adjust Talk Distance - Only One Meter. This repressive activity is carried out by the Police Criminal Investigation Unit which in its implementation involves Civil Servant Investigators in accordance with their fields which are carried out from the central to the regional level. The National Police conducted a special operation for the Cyber Police targeting the Hoax and a Special Operations for the Police targeting the "Basic Needs" for the community.

\section{REFERENCES}

Andrianita, O. (2020). New history in enforcement of mask hoarding (Head of Public Relations Bureau of the Ministry of Trade.

Bramasta, D. B. (2020). Update Virus Corona di Seluruh Dunia: Tembus 152 Negara, 80.840 Sembuh, 7.905 Meninggal. Kompas.com. Retrieved from https://www.kompas.com/tren/read/2020/03/18/080500265/ update-virus-corona-di-seluruh-dunia--tembus-152-negara-80.840-sembuh-7.905

Kumparan.com. (2020). Bagaimana Pengalaman Indonesia Tangani Kasus Flu Burung, MERS, SARS? Data Kumparan.com. Retrieved from https://kumparan.com/kumparansains/bagaimana-pengalaman-indonesiatangani-kasus-flu-burung-mers-sars-1 sow8IioMJn

Pratiwi, P. S. (2020). Update Corona 14 Maret: 96 Positif, 5 Meninggal, 8 Sembuh. CNN Indonesia. Retrieved from https://www.cnnindonesia.com/nasional/20200314160309-20-483417/update-corona-14-maret-96positif-5-meninggal-8-sembuh 
Impact of Corona Virus on Criminal Action and Prevention Measures in Indonesia

Wijaya, P. S. (2020). Kronologi Wabah Virus Corona Terbaru Menyebar dari Wuhan. Liputan6.com. Retrieved from https:/www.liputan6.com/global/read/4165114/kronologi-wabah-virus-corona-terbaru-menyebar-dariwuhan

Salazar, P. M. D., Niehus, R., Taylor, A., Buckee, C. O., \& Lipsitch, M. (2020). Using predicted imports of 2019$\mathrm{nCoV}$ cases to determine locations that may not be identifying all imported cases. Medrxiv. Retrieved from https://doi.org/10.1101/2020.02.04.20020495

Sosialisasi Virus Corona (https://technologue.id, accessed on 08/3/2020).

The Indonesian Ministry of Trade. (2020). Development of Foreign trade in the aftermath of the Corona Virus Outbreak (http://statistik.kemendag.go.id/infographic/, accessed on 8 March 2020). 